\section{Mission, Vision, and Values of Organizations, the Catalysts of Corporate Social Responsibility}

Lecturer Mihaela DUMITRAŞCU, Ph. D., Bucharest University of Economic Studies, e-mail: mihaela.dumitrascu@cig.ase.ro

Univ. Prof. Liliana FELEAĞ̈, Ph. D., Bucharest University of Economic Studies, e-mail: ililianafeleaga@cig.ase.ro

\section{ABSTRACT}

The present research explores the strategic orientation of listed companies, with a focus on their mission, vision, and values, that defines the aspirations and the goals that govern that organization. The data were collected from the official websites. Based on the literature review there were identified the main missions, values, and visions, that were grouped, after analyzing all the financial and non-financial reports, within categories, such as emphatic values/people oriented, cultural values, workplace values. Because one of the most important stakeholder within any organization is represented by the employee, the authors also grouped them within identity reflected (relational, organization, workplace, competence/professional).

Results are mixed and show that only $62 \%$ of companies disclose information regarding their vision, $85 \%$ of them disclose information regarding their mission, while $54 \%$ of companies disclose their values. The main objective of the classification is to establish a framework for a future template of corporate social responsibility.

The relevance of the research is given by the topicality of the research. The originality of the research derived from the modality of approaching the theme, from the objective of the research and also from the fact that there is an increasing interest in society, in general, for promoting accountability, respect for human rights, environment, health and security.

The objective of the present research is to highlight the important role of vision, mission and values of a company. These represents the pillars for a successful organization and may be disclosed in separated statements or may be integrated in a single statement. Their purpose is to communicate to both internal and external stakeholders the main goal of the organization.

Keywords: mission, vision, values, corporate social responsibility

JEL Classification: G30, G39, M40, M49

To cite this article:

Dumitraşcu, M., Feleagă, L. (2019), Mission, Vision, and Values of Organizations, the Catalysts of Corporate Social Responsibility,

Audit Financiar, vol. XVII, no. 1(153)/2019, pp. 142-148,

DOI: 10.20869/AUDITF/2019/153/007

To link this article:

http://dx.doi.org/10.20869/AUDITF/2019/153/007

Received: 6.11 .2018

Revised: 12.11 .2018

Accepted: 22.11.2018 


\section{Introduction}

Nowadays there is an increasing need for socially responsible organization, due to the lack of efficiency in both public and private sector and to the inconsistency of the many reforms in time.

We can imagine an ideal organization which is the accountable, the social responsible and autonomous one and whose behavior is managed by good values and visions in order to achieve the performance on long run.

Within the present study we highlight the missions, the values and the visions of organizations as they are available on the websites of the companies from our sample. By analysing the vision, the mission and the values of organizations we try to reflect the identities of companies. The most used values are also important in interpersonal relationships, such as respect, integrity etc.

The Romanian context is chosen for the present study, because we want to explore and create a radiography of the entities from our country and of the way they use to implement the concepts of social responsibility and sustainability.

The importance of the research is given by the fact that it represents a contribution to the field of corporate social responsibility, by exploring the concept, in connection with other factors, with impact on different stakeholders.

The main objective of the paper is to establish a framework for a future template of corporate social responsibility. The relevance of the research is given by the topicality of the research. The originality of the research derived from the modality of approaching the theme, from the objective of the research and also from the fact that there is an increasing interest in society, in general, for promoting accountability, respect for human rights, environment, health, and security. The objective of the present research is to highlight the important role of vision, mission, and values of a company. These represent the pillars for a successful organization and may be disclosed in separated statements or may be integrated into a single statement. Their purpose is to communicate to both internal and external stakeholders the main goal of the organization.

The estimated results will be obtained under a qualitative and a quantitative research methodology, based on the study conducted. Findings revealed that
Corporate Social Responsibility Reporting is important not only for the good reputation of the company, but also for the quality of the products or of the information delivered, for the winning of the confidence of stakeholders and also for increasing the profitability. The conclusions derived from this research are useful for both students and professionals.

Within the research process, a study was realized regarding the conceptual items. The analysis included concepts such as the degree of implementation of social responsibility, the link between social responsibility and corporate governance, as well as the categories of stakeholders involved, and the importance of social responsibility.

The main research question is what are the aspirations and the goals that govern the organization? This will be addressed both by exploring the relevant literature and through the research conducted, that investigates this issue in the context of a sample, in Romania. There were analyzed the mission, vision and values statements of organizations that contribute to sustainability creation. The mission represents the statement regarding the core purpose and must be written in the present tense. The vision represents the statement about where the organization wants to arrive and is better to be written in future tense. Values can be inspired by mission and vision and represent the way in which our employees behave or interact.

There were included in the sample the most liquid companies, those that are part of BET Index, considering that they are the ones that can represent an example of all organizations. It was selected the interpretative methodology by analyzing the financial and the non-financial reports of the companies that are parts of the sample, such as the annual reports, the CSR reports, the corporate governance reports, the sustainability reports and the vision, mission and values statements and the other information disclosed on their websites. Data were collected from the annual reports, from the corporate social responsibility reports, from the official websites of the companies and from other sources. We used the listed companies because we considered them the most representative ones.

The paper consists of an introduction, followed by the study of the literature review in the field of social responsibility, regulations and new trends in social responsibility field, the methodology of the research, the aspirations and the goals that govern the organization, 
such as mission, vision, values. Regarding the practical implications, this study can serve as a basis for future research on this topic and also may be useful to investors and to other actors of the economic life.

\section{Lïterature review on social resnonsiloility}

Companies have as main objective the profit, that is usually connected with efficiency, productivity, innovation, value added to the company (MacGregor and Fontrodona 2008: 1).

Researchers found different factors that affect social responsibility within organizations, such as different groups, social awareness, education, competitive advantage, international standards, reputation, ethical issues (Jothi, 2016), transparency, customer loyalty (Kim \& Kim, 2016).

Besides other factors, a company has a socially responsible behavior to improve its image, to better manage human resources (Maloni and Brown, 2006).

There were developed studies in order to find out the factors that affect the corporate social responsibility implementation process (Dagiliene et al, 2014, Dagilene, 2010, Habek and Wolniak, 2013), other mentioned industry and stakeholders' pressure (Fifka, 2013) and
Governments issues (Matten and Moon, 2005).

Other authors discovered factors such as promotional initiative, educational initiative, meeting the needs of stakeholders, better focus on long-term goals, improving risk management (Habek and Wolniak, 2015).

Social responsibility, accountability, and sustainability have been always the objective of many sectors of activity, and from this point of view, we focused on different sectors of activity, that have many negative impacts.

Nowadays a company involved in corporate social responsibility has a competitive advantage, contributes to sustainability, consolidates its relationship with investors, customers, suppliers, and other stakeholders. As such, it is important to observe that social responsibility can have both a negative and a positive impact.

Social responsibility has received an increased attention. Researchers have, thus, developed indices, as well as correlations and assessments. It is important to observe the link between organizational culture, the object of activity, strategies, and planning.

In practice, corporate social responsibility is interconnected with sustainability (Figure no. 1), mission, vision and values of the organization, reporting statements and relationships with stakeholders.

\section{Figure no. 1. Sustainability}

Sustainability Definitions

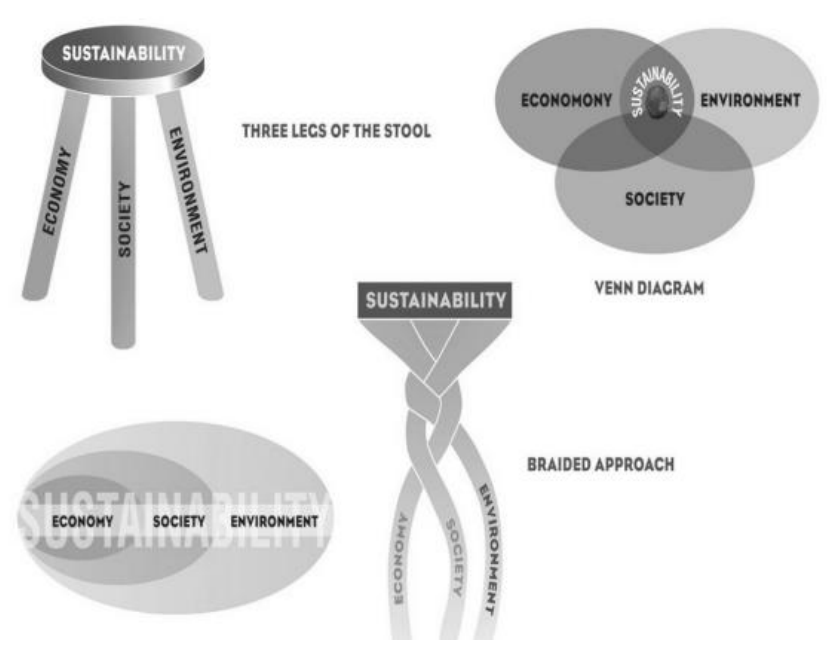

Source: https://www.ccua.com 
Organizations disclose sustainability and social responsibility reports on their websites. Companies' main objective is to present the environmental, economic and social impact. All these reports include their developed actions and activities, the progress and efforts involved. In this regard, there are guidelines, issued in order to provide organizations a framework for the preparation of social responsibility and sustainability reports. There is no specific template for these reports.

Regarding the other aspects of accounting, such as corporate governance, we observe that in Romania there were made few steps in terms of regulations and new trends in social responsibility field (Feleagă, 2011). The reason could be the changes within the legislative system: Corporate Governance Code (August 2001); OECD Report regarding the implementation of Corporate Governance in Romania (December 2001); Corporate Governance Institute (July 2003); Principles of Implementation of Corporate Governance (July 2005); Code of Corporate Governance (2008); Emergency Government Ordinance No. 109/2011 (December 2011); Corporate Governance Index (2013); Law of Corporate Governance for State-Owned Entities No. 111/2016 (May 27, 2016).

\section{Methodology and results}

Sustainability creation is provided through the mission, values and vision statement. An effective management instrument in order to draw up the strategy of an organization is the mission, values and vision statement. In order to achieve the sustainability any company needs to find its equilibrium between the financial and the non-financial performance. The study highlights the sustainability creation through mission, values, and vision.

Why we are doing what we are doing is represented by the mission of the organization.

Where we are trying to go in the near future is representing our vision.

How we are going to do about it are our values.
Even if mission, vision, and values seem to be esoteric or abstract, they are very important for any organization. The mission represents the statement regarding the core purpose and must be written in the present tense. The vision represents the statement about where the organization wants to arrive and is better to be written in future tense. The values can be inspired by mission and vision and represent the way in which company's employees behave or interact.

The study included in the sample the most liquid companies, those that are part of BET Index, considering that they are the ones that can represent an example of all organizations (Table no. 1).

\section{Table no. 1. The sample}

\begin{tabular}{|l|l|}
\hline No. & \multicolumn{1}{|c|}{ COMPANY } \\
\hline 1 & BANCA TRANSILVANIA SA \\
\hline 2 & FONDUL PROPRIETATEA \\
\hline 3 & OMV PETROM SA \\
\hline 4 & SNGN ROMGAZ SA \\
\hline 5 & BRD SA \\
\hline 6 & SNTGN TRANSGAZ SA \\
\hline 7 & SOCIETATEA ENERGETICA ELECTRICA SA \\
\hline 8 & DIGI COMMUNICATIONS NV \\
\hline 9 & CNTEE TRANSELECTRICA \\
\hline 10 & SN NUCLEARELECTRICA SA \\
\hline 11 & CONPET SA \\
\hline 12 & MEDLIFE SA \\
\hline 13 & BVB SA \\
\hline
\end{tabular}

Source: $h$ ttp://hww.bvb.ro/financialinstruments/indices/indicesprofiles

By analysing the financial and the non-financial reports of the companies that are part of the sample, such as the annual reports, the CSR reports, the corporate governance reports, the sustainability reports, the vision, mission and values statements and the other information disclosed on their websites the study discovered that only $62 \%$ of companies disclose information related to their vision (Figure no. 2), 85\% regarding their mission (Figure no. 3 ), and only $54 \%$ disclose information related to their values (Figure no. 4). 


\section{Figure no. 2. Information disclosed by companies regarding their vision}

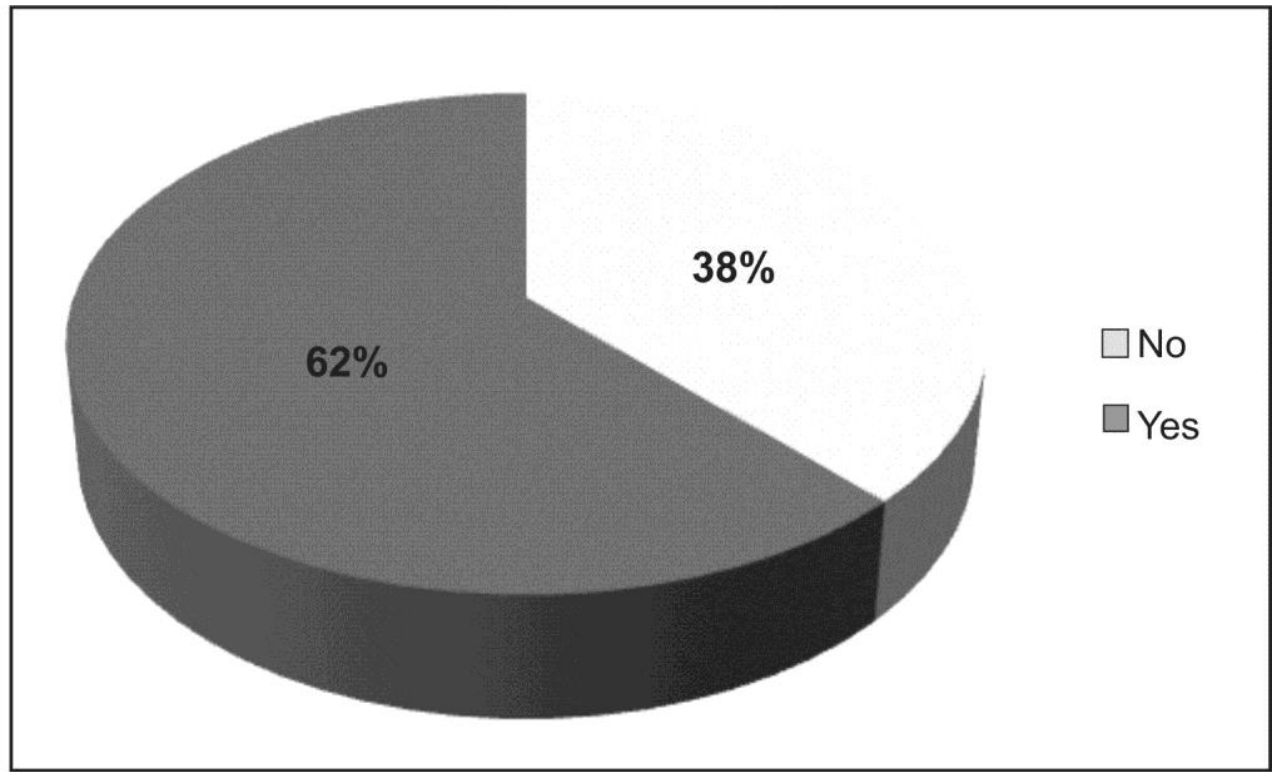

Source: Author's own projection

Figure no. 3. Information disclosed by companies regarding their mission

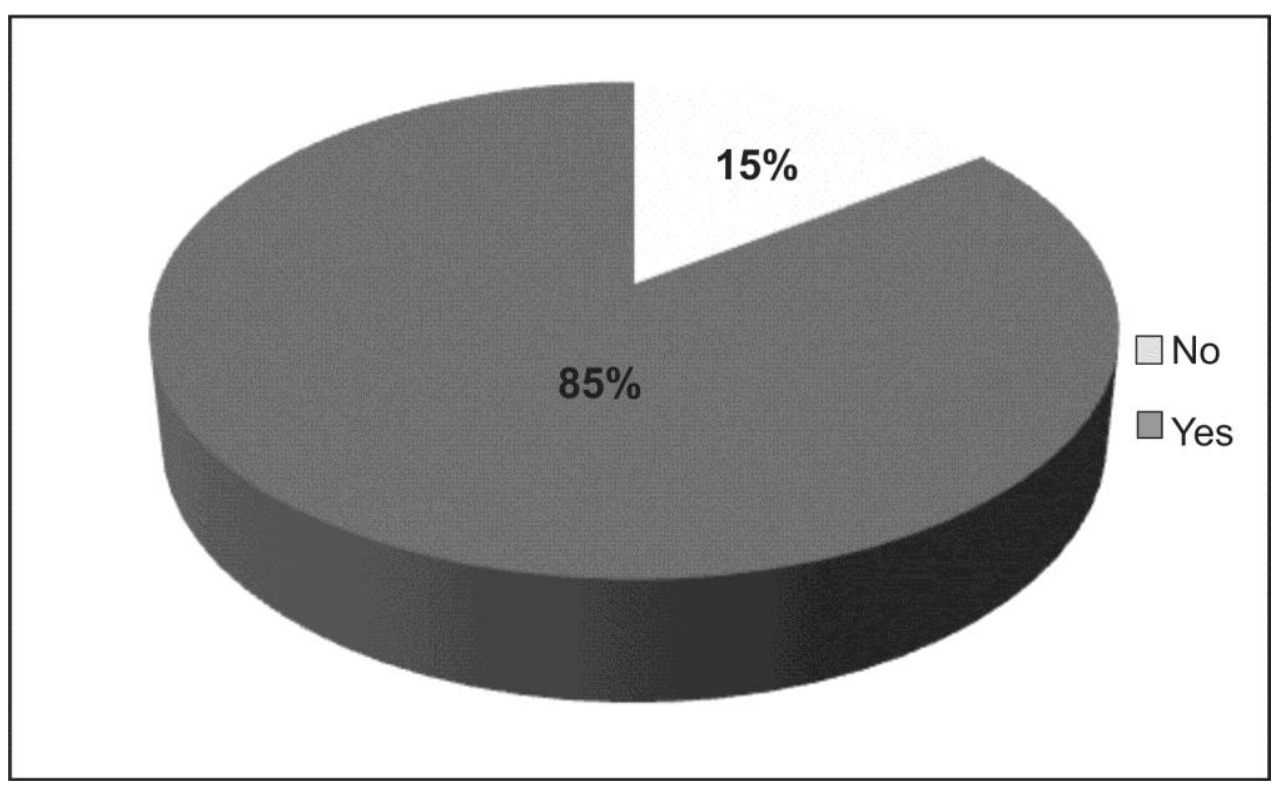

Source: Author's own projection 


\section{Figure no. 4. Information disclosed by companies regarding their value}

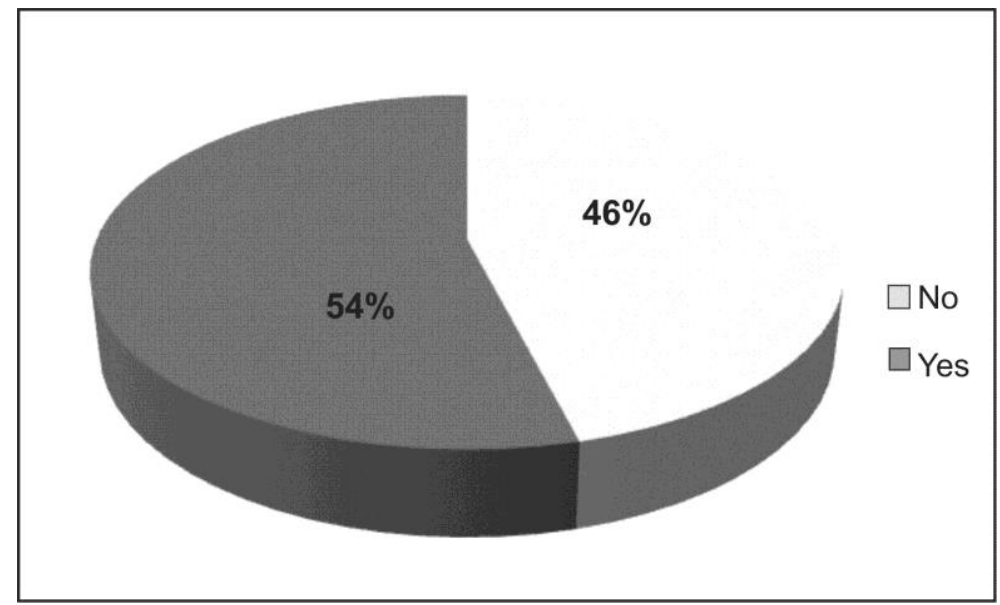

Source: Author's own projection

After analyzing all the financial and non-financial reports the values were grouped within categories in order to establish a framework for a future template of corporate social responsibility. Thus, we split within categories of values, that were grouped within:

- emphatic values/people oriented: intearity, respect, transparency, openness, compassion, customer service, responsiveness, involvement, responsibility, respect for people and environment, sustainability, transparency, dynamism, flexibility, care

- cultural values: innovation

- workplace values: teamwork, lonq life learning, security/safety, professionalism, competitivity, communication, cooperation, stability.

Because one of the most important stakeholder within any organization is represented by the employee, we also grouped them within:

- relational: implication, care, respect openness

- organization: excellence, accountability, responsibility, effectiveness, leadership, performance, sustainability, assuming social responsibility, professionalism, transparency, dynamism, flexibility, competitivity, communication, cooperation, stability

- workplace: teamwork, innovation, quality, diversity, collaboration, motivated employees

- competence/professional: knowledge, competences, innovation, long life learning, safety.

\section{Conclusions}

We live in a changing world and from this point of view we are challenged to be competitive in order to be productive and to obtain performance (Autor, 2014; Autor, 2015). Socially responsible practices nowadays must come into spotlights, being one of the basic values. The reason is that we must understand and prioritize the factors that are within the DNA of the organization.

People are responsible in their day by day activity, with the family, with the environment, with their friends, they learn about social responsibility at home, at school, at workplace, through socially responsible examples. People consider a socially responsible organization when it has a responsible attitude for its customers, for community, employees, suppliers and when it respects the rules.

Socially responsible business practices are initiatives through which a company is increasing the way of action for the wellbeing of the community and of the environment.

A company can make changes regarding:

- increasing the access to products for people with disabilities (access within shops)

- socially responsible marketing for children (no more selling dangerous products within schools)

- development of programs for the wellbeing of the employees (medical assistance, 
psychological counselling, sport and wellness activities)

- delivering fair information regarding the products (the packages contain information regarding side effects, the volume of physical activities needed in order to burn the calories or the fats of the products)

- choosing the raw materials and the packages that are eco-friendly (in order to reduce the waste, to increase the recycling process, to eliminate the toxic emissions)
- withdrawal of the products that are danqerous or illegal (for example there are companies that decided to withdraw the unhealthy food or to combine with the healthy one)

Aspects such as corporate qovernance. social responsibility and sustainability of organizations are interconnected and represent modern concepts and hot issues of developed countries, with impact on all stakeholders.

A future research direction could be the perception of decision makers (Parliament, Government) in the implementation of social responsibility, by implementing and creating an appropriate legislative framework.

\section{REFERENCES}

1. Autor, D. H. (2014). Skills, Education, and the Rise of Earnings Inequality among the 'Other 99 Percent. Science 344(6186): 843-51.

2. Autor, D. H. (2015). Polanyi's Paradox and the Shape of Employment Growth. In Re-Evaluating Labor Market Dynamics, pp. 129-79.

3. Dagiliene, L., Leitoniene, S., \& Grencikova, A. (2014). Increasing Business Transparency by Corporate Social Reporting: Development and Problems in Lithuania. Engineering Economics, 25(1), 54-61. http://doi.org/10.5755/j01.ee.25.1.2356.

4. Dagiliene, L. (2010). The research of corporate social responsibility disclosures in annual reports. Engineering Economics, 21 (2), pp. 197-204

5. Dragomir, V.D. (2012a), Sustainability reporting: a case for corporate accountability, Bucureşti, Editura ASE.

6. Feleaga, N., Feleaga, L., Dragomir, V.D. (2011). Development of Corporate Governance by Expanding the Corporate Responsibility of EU Member Countries, The Business Review Cambridge, vol 17, nr. 2.

7. Fifka, M. S. (2013). Corporate responsibility reporting and its determinants in comparative perspective - a review of the empirical literature and a meta-analysis. Business Strategy and the Environment, 22(1), 1-35. doi: 10.1002/bse.729

8. Habek, P., \& Wolniak, R. (2013). Analysis of approaches to CSR reporting in selected European
Union countries. International Journal of Economics and Research, 4(6), 79-95.

9. Habek and Wolniak, (2015). Factors Influencing the Development of CSR Reporting Practices: Experts' versus Preparers' Points of View. Inzinerine Ekonomika-Engineering Economics, 2015, 26(5), pp. 560-570

10. Jothi, M, (2016). Driving Factors of Corporate Social Responsibility Practices in India: An Empirical Study based on the Perceptions of Selected Executives from Public and Private Firms. India Amity Journal of Corporate Governance 1(1), (39-53)

11. MacGregor. S. P., Fontrodona J., (2008): Exploring the fit between CSR and Innovation, 2008 IESE Business School

12. Maloni, M. J., \& Brown, M. E. (2006). Corporate social responsibility in the supply chain: An application in the food industry. Journal of Business Ethics, 68(1), 35-52

13. Matten, C., \& Moon, J., (2005). A conceptual framework for understanding CSR. In A. Habisch, J. Jonker, M. Wegner \& R. Schmidpeter (Ed.), Corporate Social Responsibility across Europe (pp. 335-356). Berlin: Springer.

14. http://www.bvb.ro/Financiallnstruments/Indices/Indi cesProfiles [accessed on 20.10.2018]

15. https://www.ccua.com [accessed on 22.10.2018] 